\title{
Doing Business in Emerging Market Economies: Challenges and Success Strategies for Western Multinational Corporations
}

\author{
Ashford C. Chea ${ }^{1}$ \\ ${ }^{1}$ Tyron Adam Burroughs School of Business and Entrepreneurship, Benedict College, Columbia, South Carolina, \\ USA
}

Correspondence: Ashford C. Chea, Tyron Adam Burroughs School of Business and Entrepreneurship, 1600 Harden Street, Columbia, South Carolina 29229, USA.

Received: July 2, 2021

doi:10.5539/ibr.v14n9p82
Accepted: July 27, $2021 \quad$ Online Published: August 9, 2021

URL: https://doi.org/10.5539/ibr.v14n9p82

\begin{abstract}
The purpose of this paper was to investigate and analyze the negative impact of emerging economies' institutional challenges on western multinational corporations (MNCs) operating there. The content analysis methodology was used. The paper reveals that emerging markets' institutional voids affect western MNCs in terms of cost of doing business, strategy development and overall competitiveness. The conclusions derived from the analysis is that despite emerging economies investment opportunities, rapid economic and demand growth, their competitive landscape can negatively impact western MNCs ability to succeed in these markets. This is due to imprudent policies and inadequate governance structures implemented by emerging market policymakers. The article begins with a brief introductory background of emerging economies. This is followed by objectives of the paper, research method, and the theoretical underpinnings for the motivations of western MNCs to pursue overseas markets in emerging economies. It then provides an analysis of the role and significance of emerging economies in the global economy. This is followed by a critical review of MNCs strategies in emerging markets, and effects of emerging market institutional challenges on MNCs. Then, the implications for MNCs competitiveness in emerging markets are examined. Finally, recommendations for success for both prospective and current MNCs doing business in emerging economies are explored.
\end{abstract}

Keywords: multinational corporations, internationalization, strategies, emerging markets, emerging economies, institutional voids

\section{Introduction}

Over the past decades, policymakers in Asia, Latin America, Africa, and the Middle East have implemented economic reforms that promote economic openness and free-market liberalization (Hoskisson et al 2000). These nations are called emerging market economies. But despite the determination of policymakers to embrace free-market capitalism, they are characterized by government's interference, political volatility, and inadequate property rights protection (Meyer et al 2009). Despite these institutional weaknesses, emerging markets can provide opportunities for many multinational corporations seeking markets in these countries (Hoskisson et al 2000). As a result, foreign multinational corporations often establish their organizational structure not only in advanced economies with institutional stability, but also in free-market emerging economies (Dominguez, Garrido, \& Orcos, 2016).

All emerging economies share two main attributes, a fast pace of economic development and public policies promoting free-market economic liberalization (Hoskisson et al, 2000). But despite the large demand and economic growth in emerging economies and their embrace of market liberalization, these countries are still characterized by some institutional voids that lead to an unlevelled playing field and different rules for economic actors (North, 1990) than those of developed economies. (Dominguez et al., 2016).

For instance, free-market capitalism in the three big emerging economies of Brazil, India and China is mostly driven and underpinned by reciprocal mechanisms of fidelity among members of associated groups, state-business strategic alliances centered on informal personal relationship, family connections and shared socio-cultural or political affiliations. What follows from these arrangements is a limited and fragmented central government capability, fragile business associations and opaque market mechanism that leads to subpar economic achievement because businesses must deal with high uncertainty and instability (May, Nolke, \& Ten 
Brink, 2019).

Another case in point is Nigeria, where intense rivalry for state contracts, permits, and licenses has contributed to bribery in the country. This is because participation in government procurement contracts is a long and non-transparent process. Companies reportedly must allocate special resources and unspecified time to meet with government officials during which corruption often takes place. Moreover, in Nigeria, like in other emerging economies, the legal framework is woefully underdeveloped and fragile to say the least. The legal and judicial systems are inefficient, cumbersome, and very expense to use. This causes companies to engage in illegal practices such as bribery and tax evasion to escape legal institutional requirements and business uncertainties. Likewise, firms are more likely to engage in malpractices and corruption if the legal and judicial systems are ineffective and perceived as non-transparent and inequitable. (Ufere \& Gaskin, 2021).

\subsection{Objectives of the Paper}

The objectives of this article were to analyze the following: (1) the motivations of western multinational corporations to pursue investment opportunities in emerging economies; (2) the attractions of emerging economies as markets for western multinational enterprises; (3) challenges in doing business in emerging market economies; and (4) success strategies for doing business in emerging economies. The research article can best be described as a review paper.

\section{Research Method}

This paper used the content analysis methodology and techniques. It is based on the review of current and relevant literature and articles on multinational corporations doing business in emerging economies. Except where a source was required for its unique perspective on issues relating to western multinational enterprises in emerging economies, the author screened sources by "multinational corporations in emerging economies" and by other variants of keywords, targeting specifically multinational corporations in emerging economies. Sources included refereed studies, empirical and scientific reports, and articles from professional journals. Since the literature on western multinational corporations in emerging economies is voluminous, the author applied several decision rules in selecting articles. First, because the global competitive and economic environment are changing rapidly in emerging economies, the author used sources dated from 2000 to 2021. Some articles were also used for their historical context. Second, given the paper's aim to provide a pragmatic enlightenment of the main drivers and issues underpinning the motivations of multinational corporations' presence in emerging markets, the writer included, in order of priority: refereed scientific and empirical papers, reports, and other relevant literature on current trends about multinational enterprises in emerging market economies. The resulting materials contained a large volume of scientific journal articles, empirical reports, research findings, and professional documents. Finally, the author used both thematic and structured strategies to assess, separate and select which materials to review and include in this paper. All sources were then categorized by key words such as multination corporations, emerging market economies, emerging economies, foreign direct investment for the purpose of in-depth analysis. As a result, all the referenced sources provided the needed materials from which outcomes (i.e., evidence and conclusions) were derived. To get some perspective on the theoretical underpinnings that underlie the motivations of western multinational corporations' presence in emerging economies, the author began with a brief review of the theoretical literature (Chea, 2015).

\section{Theoretical Underpinnings}

Motivations for internationalization of western multinational corporations have been analyzed and debated by academics, professional, and social scientists. Many scientific investigations attribute the rationale for globalization of multinationals to acquisition of necessary competitive edge, resource endowment, and market expansion. The monopolized advantage theory (Hymer, 1976) states that firms would engage in overseas markets based on their possession of monopolized competitive strengths in relation to their local rivals. The globalization of business activity was driven by the acquisition of resources, internationalization, and geographic advantages (Arranz \& De Rroye, 2009; Zeng et al., 2012). 


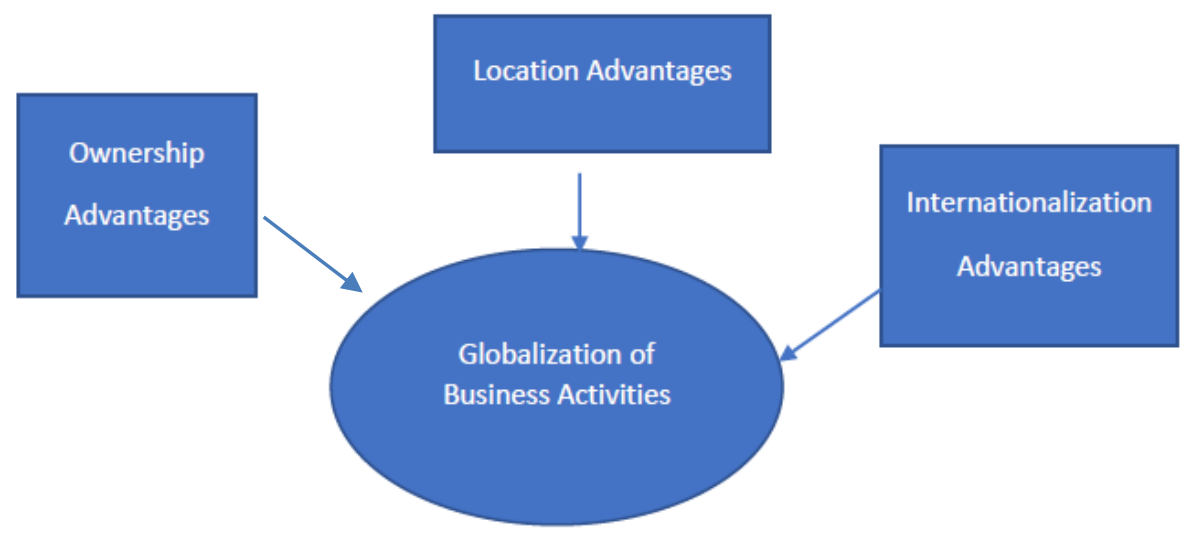

Figure 1. Driving Forces of Globalization of Business Activities

Source: Author's construct

Likewise, following the research of Coase (1937), Berkley \& Casson (1976) indicated that the contemporary firm is involved in the coordination of many integrated economic activities, including production, marketing, and distribution. They asserted that the corporation has the tendency for developing its own networks and research and development capabilities to meet its strategic requirements. The enterprise accrued the rewards from internationalization using its scientific assets, intellectual capital, and communication network internationally. The authors also indicated that the motivation to internationalize derived from several forces. These include attributes of the goods and services, scale economies, structure of competitive markets, geographical location, local variations, political and economic affiliations between nations, tax regimes, and the enterprise's leadership acumen. They further stated that the trend of globalization will progress until its advantages supersede its disadvantages. In fact, the internationalization theory agreed with Hymer's (1976) assertion that it is the ownership edge that is the main determinant for enterprises' motivation to engage in investments (greenfield and acquisitions) overseas (Yamin, 2000; Densil, Williams, \& Deslandes, 2008).

The response of local authorities in emerging economies to the changing global environment came in the form of modifications of institutional frameworks and foreign direct investment laws. In many instances the incentives used by policymakers in the form of tax credits, are termed as locational tournaments attracting many multinational corporations to their economies. Therefore, multinationals, when trying to engage in overseas investments do seek locations that provide these incentives to benefit from their ownership advantages (Densil et al., 2008). Likewise, the role of external forces in explaining business cycles in these emerging economies has implications for the relative merits of alternative approaches of internationalization and the formulation and application of optimal macroeconomic policies in these economies (Shaghil \& Loungani, 2000).

Following this theoretical foundation, the paper proceeds as follows. Section 4 provides an analysis of the roles and significance of emerging market economies in the global economy. Section 5 presents a critical review of MNCs strategies in emerging economies. Section 6 explores the negative effects of emerging economies' institutional voids on western MNCs. Section 7 examines the information and communication technology-related challenges in emerging market economies. Section 8 assesses the implications for western MNCs competitive strategies in emerging economies. Section 9 outlines recommendations for western MNCs in emerging market economies. Section 10 contains the conclusion of the paper.

\section{Emerging Markets and the Global Economy}

The role and essence of emerging markets in the world economy has risen dramatically in recent decades. Moreover, these economies are still being increasingly analyzed and scrutinized for possible root causes of their extreme experiences that seems to occur periodically, such as the 1994-95 Mexican crisis and the 1997-98 Asian crisis. How much decline in economic activity is induced in these economies because of an increase in the global price of commodities? If these emerging market economies experience a downward trend in the world price of one of their key exports, what effect does this have on their growth and international competitiveness to attract foreign direct investment? If the US monetary authority implements policy action to cool down the economy to fight potential inflation, how much would economic activity in these emerging economies get depressed? The above questions can influence emerging economies' ability to attract foreign investments. They can also inspire 
multinational corporations' decisions as to whether to enter a particular emerging market or not (Shaghil \& Loungani, 2000).

Table 1. Attributes of Emerging and Advanced Economies

\begin{tabular}{|l|l|l|l|}
\hline Economic Landscape & & Emerging Markets & Western Economies \\
\hline $\begin{array}{l}\text { Legal and institutional } \\
\text { framework }\end{array}$ & & Unstable, inconsistent, and unreliable & Stable, consistent, and reliable \\
\hline State control & & $\begin{array}{l}\text { Low but increasing wages, and worker } \\
\text { attrition. } \\
\text { Inadequate competent workers } \\
\text { availability }\end{array}$ & $\begin{array}{l}\text { High wages, } \\
\text { Sufficient competent workers availability, } \\
\text { and low worker attrition }\end{array}$ \\
\hline Labor attributes & $\begin{array}{l}\text { Tailored to rapid growth and to creating } \\
\text { new offerings }\end{array}$ & $\begin{array}{l}\text { Influenced by improving current offerings } \\
\text { Low to medium incomes. Increasing } \\
\text { middle class. Rising consumption. }\end{array}$ & $\begin{array}{l}\text { High incomes } \\
\text { Modest growth in incomes } \\
\text { Flat consumption }\end{array}$ \\
\hline Consumer attributes & $\begin{array}{l}\text { Rapidly increasing economic growth } \\
\text { rate }\end{array}$ & Low economic growth rate \\
\hline Macroeconomic environment & Rozproach & \\
\hline
\end{tabular}

Roztocki \& Weistroffer, 2008; Roztocki, 2011).

Western multinational corporations are faced with many obstacles in emerging markets. For example, they must deal with what is called the liabilities of outsidership (Zaheer, 1995; Sharma, Boyle, Mitchell, Malik, Gray, \& O'Mahony, 2018). Some of these barriers include a lack of local identity or being labelled as foreign and the lack of local cultural and market intelligence, which entails intelligence of the marketing, economic, political, cultural, and social environments. These liabilities or disadvantages make the design and development of optimal competitive strategies difficult. For instance, in emerging market economies such as India, the legal and regulatory foundations are not strong in relation to developed economies (Mair \& Marti, 2009). But the years following economic liberalization in the 1990s are characterized by the rise of a more educated consumer class. The consumer class is also a major force that influences commercial enterprises to institutionalize the prevailing market norms. Firms comprehend this societal transformation and proactively took actions before the implementation of mandatory corporate society responsibility (CSR) by the government. Enterprises are thus pressured and influenced by the regulatory and political actors in India. They safeguard their social relevance by abiding by the new societal norms and market expectations. This protects their survival, long-term profitability, and acquisition of productive assets in general (Sharma, 2012; Mittal, 2009).

Similarly, in other emerging economies, the rapid speed of economic transformation has put a focus on the challenges deriving from poor corporate ethics and corporate social responsibility. Since the 1990s there has been an increase in business recidivism in many emerging markets. According to the China Security Regulatory Commission, 266 out of 1,036 listed companies were punished for different unethical practices from 2001-2008, 93 of which were former offenders (CSRC, 2009). Moreover, China firms are also perceived as very corrupt when conducting business overseas (Transparency International, 2009; Zhenge \& Chun, 2017). Therefore, the need to deal with the local regulatory, legal, and policy diversity is inevitable regardless of a firm's international competitive strategy. Likewise, emerging economies such as Brazil, Indonesia, Nigeria, India, and Pakistan are still developing as relate to their industries and institutional landscape, which involves market and economic un-predictabilities (Sharma et.al., 2018). Khanna, Palepu, \& Sinha (2005) state that three main challenges of emerging market economies are the absence of competent intermediary structures, institutional mechanism, and tools for executing contracts (termed institutional void). Additionally, where the required institutional frameworks are implemented, their execution are not predictable. Success in emerging economies; hence for, depends on comprehending these institutional weaknesses and the capacity of the multinational corporations to adjust their competitive approaches to incorporate the host-nation's local conditions ( Sherma et al., 2018). 


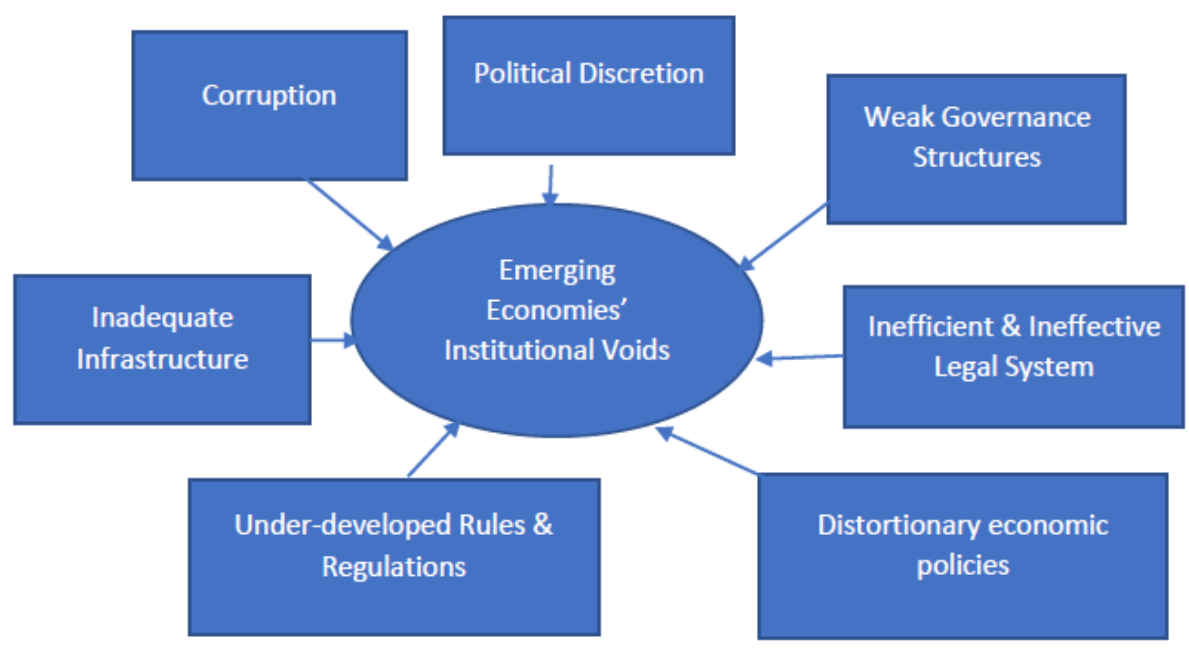

Figure 2. Elements of Emerging Economies' Institutional Voids

Source: Author's Construct.

\section{MNCs Strategies in Emerging Economies}

Most western corporations doing business in today's emerging market environment are categorized into three main structural arrangements. They are global, multi-local, and international. The specific form selected is a function of the strategic challenges each firm faces. These challenges include the need to globalize, the need to localize, or the need to specialize through technology and communication ( $\mathrm{Li}, 2002)$. Critical analysis of motivations for internationalization shows that firm engage in international business in emerging economies to take advantage of overseas investment opportunities, to response to government's incentives, to improve domestic image, and to develop international identities (Zeng, Zeng, Xie, Tam, \& Wan, 2012).



Figure 3. Main Drivers of MNCs' Motivations for Internationalization in Emerging Economies

Source: Author's Construct.

Each of these internationalization approaches is confronted with one major strategic task, that is to balance, global efficiency, local responsiveness, and technological progress and communication adequately. Today's international business landscape poses all three challenges at the same time. The integrative approach highlighted for overcoming these three strategic tasks is the transnational model. The transnational model offers a superior way to integrate global efficiency, local responsiveness and differentiation, and specialized worldwide innovation and learning within one firm ( $\mathrm{Li}, 2002)$.

This assertion assumes that the framework and arrangement of global markets are flexible during the previous thirty years that have been driven by fast evolution in scientific innovation. Also, the ascendency of human resources as wealth-creating force for economic exchange has transformed the global markets in many areas. Some of the manifestations of this transition can be seen in the service space, particularly in the areas of 
intellectual property, the increasing globalization of the business operations, the liberalization of global trade and markets, and the evolution of digital innovation (Williams \& Deslandes, 2008).

Western multinational enterprises adopting global strategies seek to acquire increased economies of scale and global efficiency through the production of standardize goods for the global markets. For example, during the beginning of its global operations, Honda implemented this model. Multinationals pursuing local responsiveness utilize a multi-local strategy that aims to cater to differences in local market's environment. These organizations tend to be involved in full value-creation in different market locations; they provide unique offerings and execute different competitive strategies suitable for each market. Proctor and Gamble adopted this model. Lastly, organizations using an international approach transplant their home markets technologies and managerial resources to overseas markets where local rivals do not possess such resources. Xerox utilized this approach $(\mathrm{Li}$, 2002). The transition in innovation strategies from the overdependence on home nation's capabilities for research and development, and marketing to an open innovation approach has led multinational corporations to provide the theoretical justification to explore the global environment for resources that assist corporations acquire and keep their competitive advantages (Fatima, 2017).

This development of global innovative frameworks has been motivated by the decline of competitive position of home country research and development. This is because of the rapid rise of migration of knowledge workers; Therefore, making it challenging for corporations to wholly capture the benefits derived from research and development initiatives. Moreover, the difficulty of organically creating all the human capital needed for innovation has motivated MNCs to pursue creative capital beyond their home markets. Laursen \& Salter (2009) notes that MNCs pursuing global sources of human capital have higher probability to innovate. Hence, placing the emphasis on human capital creation on relationships with strategic partners and alliances around the world (Fatima, 2017).

\section{Effects of Institutional Voids on Western Multinational Corporations}

The waves of institutionalization impacted multinational corporation doing business in emerging economies in different ways. Multinational corporations with organizational strategies which are at odd with the institutional norms had to recalibrate their operational strategies; they adjusted their approaches to respond to the legal and regulatory transformation in the local markets. For example, for enterprises to be profitable and compete sustainably they had to strategically realign their competitive model with institutional demand depending on the regulatory environment (Sharma, 2012); Some firms find it very hard in dealing with such reforms and exit these markets. This is because the institutional voids significantly increase the costs of doing business This also led to efficiency lost for many MNCs, a significant factor for corporate sustainability. For others it meant misalignment with market demand leading to negative impacts on their profitability in the local markets (Mittal, 2019). Another institutional void in emerging economies is corporate unethical practices. Known as corporate recidivism, it is the persistent pattern of unethical or illegal practices over time, amplifying the durability of managerial unethical behavior. Research shows that firms unethical practices not simply impact their reputation (Luo, 2005); Chun, 2006), but also has a negative spillover on other enterprises and society in general (Jonsson et al., 2009). Moreover, corporate recidivism does have greater negative impacts on firm's bottom-line and society at large (Zheng \& Chun, 2017).

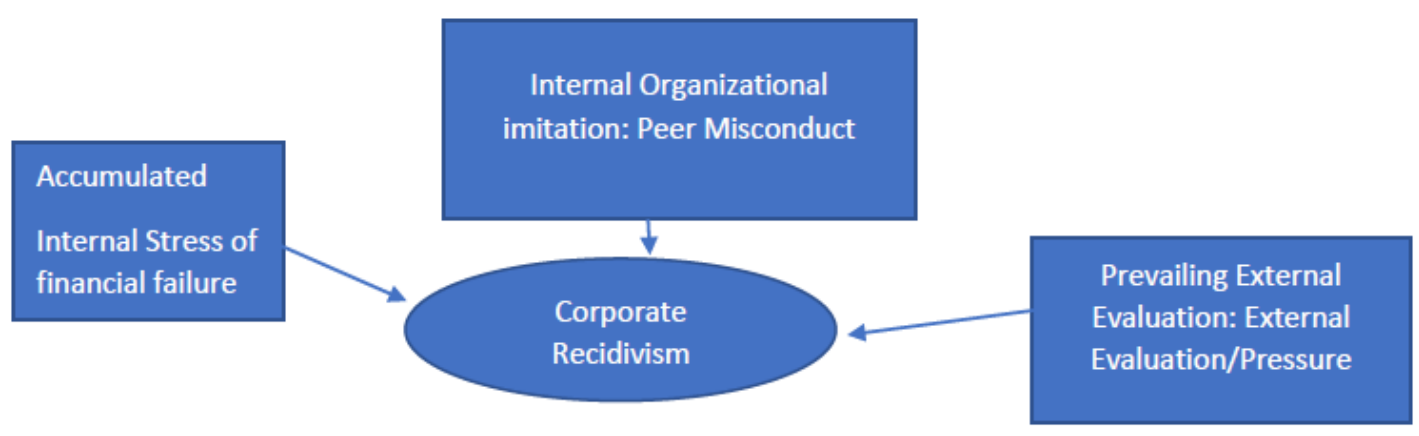

Figure 4. A conceptual model of corporate recidivism

Source: Author's Construct.

Take Nigeria for example. Business tax evasion in Nigeria is driven by perception of exorbitant tax rates, inconsistency of tax laws and a dishonest tax collection system in which tax authorities encourage tax evasion by 
accepting bribes in place of taxes due to government. Tax evasion is also inspired by an inefficient judicial system and corrupt enforcement culture, which decreases the probability of accountability and severe punishment. Corporate recidivism is very repent in Nigeria. This is evidenced by the country's ranking by Transparency International perceived corruption index. Transparency International is a global NGO that focuses on raising public education of corrupt practices in officialdom. On its 2018 Corruption Perception Indicators, it ranked Nigeria $144^{\text {th }}$ of 180 countries (Ufere \& Gaskin, 2021). Similarly, in other emerging economies, including Indonesia, Tuckey, Russia and South Africa corruption and cronyism have led many financial institutions to provide politically motivated unprofitable loans to their corporate cronies. The outcome has been an impediment to economic growth and a significant decline in firms' revenues (McFadden, 2004).

\section{Information and Communications Technology-Related Challenges in Emerging Market Economies}

Many researchers believe that information and communications technology (ICT) infrastructure is crucial to the development of emerging economies (Cronin et al., 1993; Dholakia \& Harlam, 1994). Others have asserted that unwarranted credence is attributed to ICT expansion as a driver of economic growth in emerging economies, while human capital, social capital, natural capital, and physical capital are ignored. However, advocates of ICT system paradigm believe that it expedites the mobility and transfer of capital. ICT also facilitates and coordinate global production and transportation. Moreover, ICT enables new approaches of foreign direct investments and the upscaling of operations (Antonelli, 2003; Carayannis \& Sagi, 2002). These economic functions can be seen as crucial to the world economy, in which digital integration and effective relationship network are changing the framework of economic interaction and collaboration (Ngwenyama \& Morawczynski, 2009).

In emerging economies, while only few firms develop their own technology through organic innovation, many are engaged in intellectual property theft of western innovations to their operations. This technology provides emerging market countries an opportunity to integrate into the global technological network. This is because their technological value-addition and contribution to the creative frontier is low. The probable mechanism through which global innovation is transferred to emerging economies involves commercial exchange through foreign direct investment, and licensing (Hoekman, Maskus, \& Saggi, 2005; Fatima, 2017).

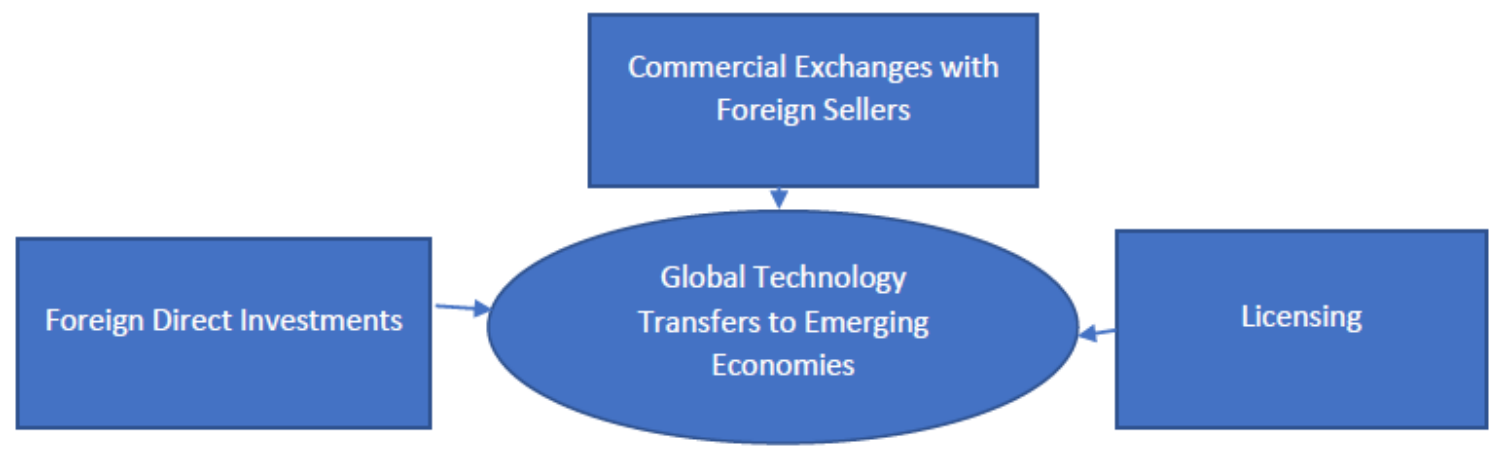

Figure 5. Transmission Channels of Global Technology Transfers to Emerging Economies

Source: Author's Construct.

New technology acquisition, adaption, expansion, and diffusion in emerging economies is path-dependent and driven by many variables, such as public policy, level of human capital development, wealth, and civil infrastructure. Some researchers have indicated that unlike advanced economies, emerging markets have very limited enabling infrastructure needed for the adoption, expansion, and utilization of ICTs (UNCSTD, 1997). As such, economic transformation through ICTs is extremely challenging. For rapid economic transformation through ICTs to be realized in emerging markets, emerging economies policymakers must create an enabling ecosystem that is supportive of ICT acquisition, adaption, and diffusion. Emerging market Governments must also recognize and deal with the obstacles that may hinder this process (Ngwenyama \& Morawczynski, 2009).

\section{Implications for Western Multinational Corporations' Competitive Strategies in Emerging Economies}

The analytical approach utilized in this paper provide insights into the institutional environment in emerging markets. It also contributes to the body of knowledge in establishing a theoretical connection between emerging market institutional deficiencies and MNCs failure. It also shed light on consumer behavior and multinational corporation strategy development across emerging markets. Optimal strategy development in emerging markets require managers of multination enterprises to study the differences in buying behavior, which exist in emerging 
economies than their home country to which they are accustomed. This is even more important especially for countries that have very different and unique social, behavioral, cultural, and economic characteristics. Considering the similarities and differences appropriate strategies for local markets are essential. For example, understanding the appropriate purchase decisions is crucial in deciding to whom and how marketing efforts should be targeted. Moreover, in cases of distinct similarities among countries, standardized marketing strategies may be adopted where identical advertising strategies can be utilized. In addition, multinational enterprises should possibly focus their marketing and communications strategies on the segments that are profitable and potential for growth. Marketing efforts, in particular communications strategies, should take into consideration the effect of how different cultures make purchase decisions (Parnell, Spillan, \& Singh, 2006).

\section{Recommendations for Western Multinational Corporation in Emerging Market Economies}

Empirical research indicates that one approach used by multinationals to manage institutional differences in emerging economies is to work with local partner organizations. Multinational corporations can overcome limitations and institutional barriers by seeking partner organizations that can assist them fill voids (Khana \& Rivkin, 2001). Moreover, MNCs need to influence the institutional environment by forging strategic partnerships (Hitt, Harrison, Ireland, \& Best, 1998), establishing alliance and networks (Khana \& Rivkin, 2001) and relying strategically on personal connections with locals (Peng \& Luo, 2000). When formal rules and the infrastructures of market economies are not evolved significantly, MNCs' strategic decisions must be driven by networks, relying on mutual personal connections. Research indicates that the significance of strategic relations is because of the under-development of the institutional underpinnings. (Buckley, 2004). Entering professional and personal relationships can occur via a joint venture or strategic alliance that assists in breaking down the burden derived from foreign identity (Johnson \& Vahlne, 2009; Khanna \& Rivkin, 2001). Notwithstanding, given this situation, MNCs should recalibrate and align their strategies to the new institutional environments to certain degrees. They must also understand when institutional differences require local partner knowledge. Lastly, MNCs should be proactive when market and cultural conditions in the emerging economies are not consistent and reconcilable with their home countries practices (Sharma et al., 2018).

Western multinational corporations should consider the consumers' structure in emerging markets; especially, consumers with very little disposal incomes. They should take into consideration the economic reality that distribution of incomes shows emerging economies possess a relatively large low-income consumers, a high-income minority, and a small but rapidly growing middle class segment. Consequently, emerging market consumers prefer to purchase cheaper but good quality products. While lower priced products should be given a larger portion in their product lines, higher priced and luxury items should be targeted at customers with higher disposal incomes. Moreover, emerging markets are countries with many languages and cultures. This can, result in different consumer attitudes towards product offerings and reaction to marketing initiatives. Therefore, MNCs should adopt different competitive strategies in different locations within each individual emerging market. Since many emerging economies have adopted western consumer materialism, foreign products can be successful in these markets if strategies are aligned with local tastes, attitudes, and culture (Ozsoy \& Apil, 2005).

Likewise, western multinational enterprises are advised to use TVs, radios, and newspapers for advertising their offerings because of the effectiveness of these tools. Billboards can serve as a substitute for TVs where there is a lack of reliable electricity. Marketing initiatives targeting low-income consumers should emphasize public transportation, direct contact, and leaflet distribution in residential areas. TV commercials, soap operas, news and sporting events are also suitable channels to reach low-income consumers. Marketing efforts targeting the middle class and relatively rich customers should use supermarkets, TV and radio programs, advertising banners in the streets, email messaging, and the internet. Unlike the advanced economies, most of the retail transactions occur in the market- places. Stores and supermarkets are considered more expensive and luxury shopping places. MNCs, therefore, should focus on marketplaces while they develop their distribution networks with local independent distributors (Ozsoy \& Apil, 2005).

Finally, Western firms competing in emerging markets should align their strategies with host the country's institutional changes to remain economically sustainable and device ways to be efficient in their operations (Mittal, 2019).

\section{Concluding Remarks}

An emerging economy has two main characteristics. The first is its rapid pace of economic development. The second attribute is that public policies favor market competition (Hoskisson et al., 2000). However, despite the fast economic output, growing consumer demand in emerging markets, and policies toward economic liberalization, these countries are still challenged by institutional weaknesses that can cause uneven playing field 
and different rules of the game that favors local firms (North, 1990) than those of western nations (Dominguez et al., 2016).

Most emerging economies need to reform their regulatory and legal institutions. They also need economic policy reforms. China, for example, while having implemented market liberalization, still favors local firms including its state-owned enterprises. This makes it difficult for foreign multinationals to compete on an even playing field in China. Foreign multinationals in China also face barriers in their growth and market opportunities. By the same token, India, a liberal democracy, is facing economic, structural, and political problems in many areas, creating obstacles for MNCs to enter, expand, and be competitive in its market (Salehizadeh, 2007).

Hitt et al. (2000) brings to the spotlight the challenges of MNCs in doing business in emerging economies. This is because business, economic, and political upheaval in emerging economies can result in policy opacity, political discretion, and unpredictability regarding the terms of contracts and other economic engagements. Also, the financial sections are inefficient, non-transparent, and underdeveloped. Therefore, there is too much instability and uncertainties in making investment decisions. Moreover, Hoskisson et al. (2000) note that emerging economies are characterized by poor legal system, insufficient intellectual property rights safeguard, policy risk that can encourage corrupt practices by market agents. Lack of adequate Information and market risk are other challenges foreign multinationals must deal with in emerging economies. These challenges can substantially raise the costs of doing business. They also make professional and personal connection very crucial to mitigate the risks associated with the poor legal and regulatory underpinnings (Johanson \& Vahine, 2009). For this reason, emerging markets are a more challenging environment for doing business than developed markets in the West. This is because advanced economies have strong legal and regulatory infrastructure. They also pose low information risk to economic and market actors (Myer et al., 2009; Dominiguez et al., 2016).

In conclusion, under condition of changing global trade policies toward economic openness for global investments, international expansion has become a crucial approach for western multinational corporations to take advantage of their unique capabilities, harness global resources or to reduce manufacturing expenditures. From the emerging economies' perspective, foreign direct Investment is seen as a driver of economic growth, technology transfer, managerial innovation, and job creation in the local economy (Perez, 1997). However, multinational enterprises do not always enhance their operations and financial fortunes after their foreign expansion. This is because, in addition to the market risks taken, MNCs also face institutional deficiencies, political and economic uncertainties in the host country. This can lead to high uncertainties in operations and long-term strategies. These forces may prevent western MNCs from making profits in the long-term. It can also lead to the failure of uncompetitive and unconnected MNCs (Huang, Chieh-Tse, \& Yang, 2013). Finally, through a mix of critical review of the literature and concrete examples-from China to India to Nigeria, the contribution of this paper to the empirical and theoretical literature on MNCs and emerging markets is the theoretical establishment of the connection between MNCs failure in emerging markets and the institutional weaknesses of emerging economies.

\section{References}

Ahmed, S., \& Loungani, P. N. (2000, Jan-Jun). Business cycles in emerging market economies. Money Affairs, $87-111$.

Arranz, N., De Rroye, J. C F. (2009). Internationalization process of Spanish small firms' strategies, transactions, and barriers. International Small Business Journal, 27, 420-441. https://doi.org/10.1177/0266242609334968

Buckley, P. J. (2004). The role of China in the global strategy of multinational enterprises. Journal of Chinese Economic and Business Studies, 2(1), 1-25. https://doi.org/10.1080/14765280310001631354

Buckley, P. J., \& Casson, M. (1976). The future of the multinational enterprises. London: MacMillan. https://doi.org/10.1007/978-1-349-02899-3

Carayannis, E. G., \& Sagi, J. (2002). Exploiting opportunities of the new economy: Developing nations in support of the ICT industry. Technovation, 22(3), 517-524. https://doi.org/10.1016/S0166-4972(01)00046-3

Chea, A. (2015). The euro zone economic crisis and sub-Saharan Africa's real economy: Analysis and the way forward. Business and Economic Research, 5(2), 255-269. https://doi.org/10.5296/ber.v5i2.8594

China Securities Regulatory Commission. (2009). The disclosure of administrative sanctions on the behaviors that violate laws and regulations on the market. Retrieved June 1, 2021 from http://www.csrc.gov.cn/pub/csrc_en/regulatory/ 
Chun, R. (2006). Ethical character and virtues: An empirical assessment and strategic implications. Journal of Business Ethics, 57(3), 269-284. https://doi.org/10.1007/s10551-004-6591-2

Coase, R. H. (1937). The nature of the firm. Economica, 4, 386-405. https://doi.org/10.1111/j.1468-0335.1937.tb00002.x

Cronim, F. J., Parker, E, B., Colleran, E. K., \& Gold, M. A. (1993). Telecommunications infrastructure investment and economic development. Telecommunications Policy, 17(3), 415-430. https://doi.org/10.1016/0308-5961(93)90013-S

Dholakia, R. R., \& Harlam, B. (1994). Telecommunications and economic development. Telecommunications Policy, 18(3), 470-477. https://doi.org/10.1016/0308-5961(94)90015-9

Dominguez, B., Garrido, E., \& Orcos, R. (2016). Multimarket contact and performance: Evidence from emerging economies. Business Research Quarterly, 19, 278-288. https://doi.org/10.1016/j.brq.2016.02.003

Dunning, J. H. (1988). The eclectic paradigm of international production: A restatement and some possible extension. Journal of International Business Studies, 19(1), 1-31. https://doi.org/10.1057/palgrave.jibs.8490372

Fatima, S. T. (2017). Globalization and technology adoption: Evidence from emerging economies. The Journal of International Trade \& Economic Development, 26(6), 724-758. https://doi.org/10.1080/09638199.2017.1303080

Hitt, M. A., Dacin, M. T., Levitas, E., Arregle, J. L., \& Borza, A. (2000). Partner selection in emerging and developed market contexts: Resources-based and organizational learning perspectives. Academy. Management Journal, 43(3), 449-467. https://doi.org/10.2307/1556404

Hitts, M., Harrison, J., Ireland, R. D., \& Best, A. (1998). Attributes of successful and unsuccessful acquisitions of U.S firms. British Journal of Management, 9(2), 91-114. https://doi.org/10.1111/1467-8551.00077

Hoekman, B. M., Maskus, K. E., \& Saggi, K. (2005). Transfer of technology to developing countries: Unilateral and multilateral policy options. World Development, 33(10), 1587-1602. https://doi.org/10.1016/j.worlddev.2005.05.005

Hoskisson, R. E., Eden, L., Lau, C. M., \& Wright, M. (2000). Strategy in emerging economies. Academy of Management Journal, 43(3), 249-267. https://doi.org/10.2307/1556394

Huang, C., Chieh-Tse, T., \& Yang, C. (2013). FDI modes and parent firms' productivity in emerging economies: Evidence from Taiwan. The Journal of International Trade \& Economic Development, 22(8), 1240-1268. https://doi.org/10.1080/09638199.2012.654401

Hymer, S. H. (1976). The international operation of national firms: A study of direct foreign investment. Cambridge, MA: The MIT Press.

Johanson, J., \& Vahlne, J. E. (2009). The Uppsala internationalization process model revisited: From liability of foreignness to liability of outsidership. Journal of International Business Studies, 40(9), 1411-1431. https://doi.org/10.1057/jibs.2009.24

Jonsson, S., Greve, H. R., \& Fujiwara-Greve, T. (2009). Undeserved loss: The spread of legitimacy loss to innocent organizations in response to reported corporate deviance. Administrative Science Quarterly, 54(2), 195-228. https://doi.org/10.2189/asqu.2009.54.2.195

Khanna, T., Palepu, K. G., \&Sinha, J. (2005). Strategies that fit emerging markets. Harvard Business Review, 83(6), 4-19.

Khanna, T., \& Rivkin, J. W. (2001). Estimating the performance effects business groups in emerging markets. Strategic Management Journal, 22(1), 45-74. https://doi.org/10.1002/1097-0266(200101)22:1<45::AID-SMJ147>3.0.CO;2-F

Laursen, K., \& Salter, A. (2009). Open for innovation: The role of openness in explaining innovation performance among U. K. manufacturing firms. Strategic Management Journal, 27(2), 131-150. https://doi.org/10.1002/smj.507

Li, M. (2002). Global strategies for domestic firms in emerging economies in a world of multinationals: Toward a model. Western Academy of Management, 7(13), 39-52.

Luo, Y. (2005). An organizational perspective of corruption. Management and Organization Review, 1(1), 119-154. https://doi.org/10.1111/j.1740-8784.2004.00006.x 
Mair, J., \& Marti, I. (2009). Entrepreneurship in and around institutional voids: A case study from Bangladesh. Journal of Business Venturing, 24(5), 419-435. https://doi.org/10.1016/j.jbusvent.2008.04.006

May, C., Nolke, A., \& Blank, T. T. (2019). Public-private coordination in large emerging economies: The case of Brazil, India, and China. Contemporary Politics, 25(3), 276-291. https://doi.org/10.1080/13569775.2018.1555781

McFadden, D. (2004). Hot money and cold comfort: Global capital movement and financial crises in emerging economies. Economiay Desarrollo, 135(1), 9-28.

Meyer, C. R., Estrin, S., Bhaumik, S. K., \& Peng, M. W. (2009). Institutions, resources, and entry strategies in emerging economies. Strategic Management Journal, 30(1), 61-80. https://doi.org/10.1002/smj.720

Mittal, S. (2019). Corporate social responsibility movement in an emerging economy: An institutional and social movement explanation. Journal of Public Affairs, 20, e2030. https://doi.org/10.1002/pa.2030

Ngwenyama, O., \& Morawczynski, O. (2009). Factors affecting ICT expansion in emerging economies: An analysis of ICT infrastructure expansion in five Latin American countries. Information Technology for Development, 15(4), 237-258. https://doi.org/10.1002/itdj.20128

North, D. C. (1990). Institutions, institutional change, and economic performance. Cambridge University Press. https://doi.org/10.1017/CBO9780511808678

Ozsoy, I., \& Apil, A. R. (2005). The emerging marketing environment in Georgia as a transition economy. Journal of Academic Studies, 25(7), 73-90.

Peng, M. W., \& Luo, Y. (2000). Managerial ties and firm performance in a transition economy: The nature of a micro-macro link. Academy of Management Journal, 43(3), 486-501. https://doi.org/10.2307/1556406

Perez, T. (1997). Multinational enterprises and technology spillovers: An evolutionary model. Journal of Evolutionary Economics, 7(2), 169-92. https://doi.org/10.1007/s001910050040

Parnell, J. A., Spillan, J. E., \& Singh, N. (2006). Strategy through the eyes of the consumer: An exploratory study across emerging economies. Panorama Socioeconomico, 24(33), 50-64.

Roztocki, N., \& Weistroffer, H. R. (2008). Information technology in transition economies. Journal of Global Information Technology Management, 11(44), 2-9. https://doi.org/10.1080/1097198X.2008.10856476

Roztocki, N., \& Weistroffer, H. R. (2011). Information technology success factors and models in developing and emerging economies. Information Technology for Development, 17(3), 163-167. https://doi.org/10.1080/02681102.2011.568220

Salehizadeh, M. (2007). Emerging economies' multinationals: Status and prospects. Third World Quarterly, 28(6), 1151-1166. https://doi.org/10.1080/0143-6590.70.1507586

Sharma, D. (2012). Evolution of an organizational field and its institutions: Study of mobile telephony in India, 1990-2010. A Doctoral Dissertation at the Indian Institute of Management Bangalore.

Sharma, N., Boyle, B., Mitchell, R., Malik, A., Gray, S., \& O’Mahony, B. (2018). Leveraging the common and outsourcing the distinct: Institutional differences and multinational company identity in emerging economies. Social Identity, 24(5), 564-581. https://doi.org/10.1080/13504630.2017.1386374

Transparency International. (2009). Global Corruption Report: Corruption and the private sector. Cambridge: Cambridge University Press.

Ufere, N., \& Gaskin, J. (2021). Evasive entrepreneurship: Circumventing and exploiting institutional impediments for new profit opportunity in an emerging market. PLOS ONE, 16(2), e0247012. https://doi.org/10.1371/journal.pone.0247012

UNCSTD. (1997). Information and communication technologies in development. Retrieved from http://www.unesco.org/webworld/telematics/uncstd.htm

Williams, D. A., \& Deslandes, D. (2008). Motivation for service sector foreign direct investments in emerging economies: Insights from the tourism industry in Jamaica. The Round Table, 97(396), 419-437. https://doi.org/10.1080/00358530802057293

Yamin, M. (2000). A critical re-evaluation of Hymer's contribution to the theory of the transnational corporations. In C. N. Pitelis \& R. Sugden (Eds.), The Nature of the Transnational Firm. London: Routledge.

Zaheer, S. (1995). Overcoming the liability of foreignness. Academy of Management Journal, 38(2), 341-363. 
https://doi.org/10.2307/256683

Zeng, R., Zeng, S., Xie, X., Tam, C., \& Wan, T. (2012). What motivates firms from emerging economies to go internationalization? Technological and Economic Development of Economy, 18(2), $280-298$. https://doi.org/10.3846/20294913.2012677588

Zheng, Q., \& Chun, R. (2017). Corporate recidivism in emerging economies. Business Ethics: A European Review, 26(1), 63-79. https://doi.org/10.1111/beer.12132

\section{Copyrights}

Copyright for this article is retained by the author(s), with first publication rights granted to the journal.

This is an open-access article distributed under the terms and conditions of the Creative Commons Attribution license (http://creativecommons.org/licenses/by/4.0/). 